\title{
Uma nova interpretação da teoria do régio vicariato indiano*
}

\author{
A New Interpretation of the Theory of the Royal Vicariate in the Indies
}

Fernando de Arvizu**

\section{REFERÊNCIA}

ARVIZU, Fernando de. Uma nova interpretação da teoria do régio vicariato indiano. Revista da Faculdade de Direito da UFRGS, Porto Alegre, n. 43, p. 3-35, ago. 2020. DOI: <https://doi.org/10.22456/01046594.105984>.

\section{RESUMO}

Este artigo discorre sobre o papel da teoria vicarialista no projeto de catequização levado a cabo nas Índias ao longo dos séculos XVI e XVII, além de informar a participação das monarquias católicas neste processo. $\mathrm{O}$ autor oferece uma visão sobre as questões políticas subjacentes ao desenrolar dessa teoria no período citado e, por fim, aponta para alguns dos seus impactos na América e na Europa, contrastada ao cenário das nascentes Igrejas Reformadas.

\section{PALAVRAS-CHAVE}

Teoria vicarialista. Patronato. Juan de Focher. Juan de Solórzano Pereira.

\section{ABSTRACT}

This article discusses the role of vicarial theory in the catechization project carried out in the Indies throughout the 16th and 17th centuries, appraising the participation of catholic monarchies in this process. The author offers an insight into the political issues underlying the development of this theory in the aforementioned period and, finally, points to some of its impacts in America and Europe, in contrast to the scenario of the dawning Reformed Churches..

\section{KEYWORDS}

Vicarial theory. Patronage. Juan de Focher. Juan de Solórzano Pereira.

\section{SUMÁRIO}

1. Introdução e estado da questão. 2. Em direção à formulação da teoria vicarial. 3. Aspectos políticos da formulação da teoria vicarial. 4. A consagração política da teoria por Juan de Solórzano Pereira. 5. A reprovação da teoria vicarial. 6. Recapitulação do caráter perverso da teoria vicarial. 7. Atitude da Santa Sé. 8. A atitude da Espanha para com Roma. 9. A questão do protestantismo. 10. Conclusões. Referências. Dados da publicação.

\footnotetext{
* Publicação original em língua espanhola: ARVIZU, Fernando de. Una nueva interpretación de la teoría del regio vicariato indiano. Ius canonicum, v. 36, n. 71, p. 63-99, 1996. Tradução para a língua portuguesa por Denis Guilherme Rolla (Mestre em História do Direito, PPGDir-UFRGS). Revisão da tradução por Alfredo de J. Flores (PPGDir-UFRGS).

** Fernando de Arvizu y Galarraga, Doutor em Direito pela Universidade de Navarra (Pamplona, Espanha), foi professor nas universidades de Santiago de Compostela e Oviedo e, na Universidade de León, obteve a cátedra de História do Direito no ano de 1980.
} 
"Pues el Padre Focher es muerto, todos podemos decir que quedamos en tinieblas"

(Epitáfio de Fr. Alonso de la Veracruz a la Memoria de Fr. Juan de Focher)

\section{INTRODUÇÃO E ESTADO DA QUESTÃO}

Faz alguns anos, comecei a interessar-me pelo pensamento de alguns autores que se ocuparam do Direito indiano a e cujo pensamento estava impregnado de regalismo. Especial impacto me causou Don Pedro Frasso, a quem dediquei dois estudos, um à sua obra e outro à controvérsia que teve com o bispo de Lima, D. Melchor de Liñán, assessorando o vice-rei duque de La Palata sobre a imunidade eclesiástica ${ }^{1}$. Sua agudeza, elegância e aporte doutrinário do ponto de vista jurídico estavam muito acima do que o padre Avendaño poderia oferecer em sua pesada obra, o Thesaurus Indicus, ao qual dediquei outro estudo ${ }^{2}$.

A partir de ambas obras, bem como de informação que tive que lidar sobre outros autores - por exemplo, Salgado de Somoza ${ }^{3}$ - comecei a interessar-me pela teoria do régio vicariato espanhol nas Índias. Da leitura da maior parte dos trabalhos dedicados ao tema, tirei esta conclusão: se os dados não são conhecidos em sua prática totalidade, a interpretação dos mesmos deixava na obscuridade um aspecto que me pareceu substancial, tanto na origem, como no desenvolvimento e aplicação da teoria - o aspecto político.

Com efeito, venho mantendo desde faz algum tempo que historiadores do direito tendem a ter respeito demais para com as normas, passando por alto no que se refere ao

a Nota de tradução: o sentido de "indiano" no presente texto é referente às Índias ocidentais, como eram chamados os territórios da Coroa espanhola particularmente na América. Por isso, normalmente tem o significado correspondente a hispano-colonial.

1 ARVIZU, Fernando de. El pensamiento regalista de Don Pedro Frasso en su obra 'De Regio Patronatu Indiarum'. Revista Chilena de Historia del Derecho, Santiago de Chile, n. 12, 1986, p. 29-51; ARVIZU, Fernando de. Don Pedro Frasso y la inmunidad eclesiástica. Anuario de Historia del Derecho Español, Madri, n. 56, 1986. p. 521-541. Incidentalmente, é pertinente acrescentar aos dados biográficos de Frasso, publicados no primeiro dos trabalhos citados (ARVIZU, El pensamento regalista..., p. 29 et seq.), os oferecidos por trabalho recentemente publicado: ARRIETA ALBERDI, Jon. El Consejo Supremo de la Corona de Aragón (1494-1707). Zaragoza: Instituto Fernando el Católico, 1994. p. 613. Com efeito, Frasso abandonou Lima em 1691, quando foi nomeado Regente do Consejo de Aragón, ao qual acedeu em 1692. Ocupou o posto por muito pouco tempo, já que faleceu em 27 de novembro de 1693. Ainda continuam perdidos os seus comentários à Recopilación de 1680, mas é possível que eles possam ser encontrados entre a documentação de Frasso relativa à sua passagem pelo Consejo de Aragón. A pista merece ser investigada.

2 ARVIZU, Fernando de. El pensamiento jurídico del P. Diego de Avendaño, S.I. Notas de interés para el Derecho Indiano. In: Actas del IX Congreso del Instituto Internacional de Historia del Derecho Indiano. v. I. Madri: Universidad Complutense, 1991. p. 137-150. Seu pouco compromisso com a teoria do vicariato foi posto em evidência em: LOPETEGUI, León; ZUBILLAGA, Félix. Historia de la Iglesia en la América española. v. I. Madri: BAC, 1965. p. 151 et seq.

3 Sobre este, existe a obra: ALONSO, Santiago. El pensamiento regalista de Francisco Salgado de Somoza (1595-1665): Contribución a la historia del Regalismo español. Salamanca: Instituto San Raimundo de Peñafort C.S.I.C, 1973. 
componente político que nelas se esconde, seja como razão, seja como uma consequência das mesmas. Da mesma forma, quando se estudam as teorias de governo, pode-se cair na tentação de deixar a política de lado. O que é especialmente grave no presente caso, uma vez que a teoria vicarial é algo substancialmente político, é toda ela política. E assim, ou bem se dá uma visão incompleta, ou então - no desejo de conciliar atitudes não somente contraditórias entre a Igreja e o Estado, quando não de pouca lisura - pode apresentar-se como tentativa uma análise apolítica, evitando qualquer componente escandaloso na interpretação do vicariato indiano.

Assim, pretendo fazer exatamente o contrário, porque acredito que é precisamente o que está faltando nos estudos que foram publicados durante o último meio século. Sobram muitos dados e muita exposição asséptica, e falta iluminação do 'lado obscuro' da questão. Não pretendo ter toda a razão, ainda que pense que meu caminho não está errado. Simplesmente tratarei de expor meu pensamento, fruto de uma reflexão de anos sobre os dados que os estudos publicados nos têm oferecido. Essa reflexão leva a uma visão negativa da teoria, que ajudará - isso me parece seguro - para a melhor compreensão da mesma.

Importa liberar-se inclusive de qualquer complexo, na hora de descrever o que se pensa, sempre e quando se apoie e fundamente o que se afirma. E o que penso é que essa teoria é uma teoria perversa.

É perversa em suas origens, pois não nasce para uma melhor evangelização dos índios. Nasce para salvaguardar isenções de religiosos frente aos bispos. É perversa em sua assunção pelos juristas régios, que se encontram com uma arma formidável para prescindir - na medida do possível - do poder pontifício em tudo que é relacionado ao governo espiritual das Índias. E eles irão de buscar argumentar, difundir e sacralizar essa teoria, proibindo toda discussão sobre a mesma, sob o pretexto de que seria atacar as regalias da Coroa.

Mas existe outra perversão, quiçá mais sutil, e, por isso talvez, ainda pior que as outras duas. E esta se dá em Roma, porque também lá o vicariato indiano é visto como uma luta entre dois poderes, o real e o pontifício. Sem prescindir da evangelização dos fiéis, esta aparece num segundo plano. Digamos claramente: cada vez mais me inclino a pensar que a condenação da obra de Solórzano, por parte de Antonio Lelio de Fermo, obedece muito mais a um desquite de suas amarguras passadas em Madri do que um exame frio e desapaixonado de sua obra.

E, tudo isso, nos primeiros 100 anos da teoria vicarial. Já sabemos que, no século XVIII, esta ficará fora da discussão na Espanha, e será defendido por pessoas leigas, inclusive 
em suas ideias, muito mais inclinados a ver um poder temporal no Papado do que qualquer outra coisa. Mas isso já não nos interessa, porque é admitido por todos. O que nos interessa é mostrar essas perversões nos indícios da vida do vicariato indiano, que é o que, até agora, está semioculto ao longo de muitos estudos e de muitas páginas.

Vamos examinar os principais, comentando brevemente a sua importância. O padre Leturia publicou uma breve análise do vicariato indiano, expondo os pensamentos de Focher e de outros tratadistas, detalhando a continuação os atos do Consejo de Indias (Conselho das Índias) e da Congregação de Propaganda Fide. Nele, destaca - sem incidir demasiadamente, mas também sem ocultar - alguns aspectos políticos, em particular um testemunho do bispo de Cuzco, que definiu o passe régio como um luteranismo. Ou também algo que aparece com alguma frequência no pensamento de alguns religiosos: contra o Conselho das Índias, vale o que beneficia aos religiosos, e não o que os prejudica ${ }^{4}$.

O próprio Leturia também estudou a condenação de Solórzano Pereira por Antonio Lelio $^{5}$. Trata-se de um trabalho corajoso, onde são dadas as chaves da atitude beligerante de Lélio contra Solórzano: sua estância em Madri e seus confrontos com os Conselhos de Castela e das Índias. O próprio Leturia o diz claramente: para Lelio - ao chegar em Roma - foi oferecida uma boa ocasião para desquitar-se, cumprindo por outra parte com seu próprio dever ${ }^{6}$. Devemos chamar a atenção para a ordem em que as duas coisas são declaradas: primeiro, o desquite; logo, o dever.

Deve-se à pluma do padre Egaña a obra mais extensa sobre o tema ${ }^{7}$. Esta monografia clássica aborda todos os aspectos da questão, desde o seu fundamento até a definitiva entronização no século XVIII. Especialmente interessantes são os cinco primeiros capítulos, em que se discorre sobre os primeiros cem anos do vicariato. Neles, demonstra-se que as concessões pontifícias, em um primeiro momento, não foram tomadas pelos reis como base do vicariato. Em momento posterior se deverá ter em conta essas questões com detalhe.

O professor De la Hera escreveu faz algum tempo sua também clássica obra sobre o regalismo bourbônico ${ }^{8}$; mas muito mais interessante para nosso objeto seria outra, muito recente, onde ele aborda, sem complexos, muitos aspectos políticos do vicariato, o que

4 LETURIA, Pedro de. El regio vicariato de Indias y los comienzos de la Congregación de Propaganda. In: LETURIA, Pedro de. Relaciones entre la Santa Sede e Hispanoamérica: I. Época del Real Patronato, 1493-1800. Caracas: Sociedad Bolivariana de Venezuela, 1959. p. 101-152.

5 Idem. Antonio Lelio de Fermo y la condenación del 'De Indiarum Iure' de Solórzano Pereira. In: LETURIA, Pedro de. Relaciones entre la Santa Sede e Hispanoamérica: I. Época del Real Patronato, 1493-1800. Caracas: Sociedad Bolivariana de Venezuela, 1959. p. 335-408.

6 Ibidem, p. 335-408.

7 EGAÑA, Antonio de. La teoría del Regio Vicariato español en Indias. Roma: Università Gregoriana, 1958. 8 HERA, Alberto de la. El regalismo borbónico en su proyección indiana. Madri: Rialp, 1963. 
significou, para quem aqui escreve, uma verdadeira luz sobre este 'lado obscuro' anteriormente mencionado ${ }^{9}$. Em particular, no capítulo VII, dedicado ao exame do patronato, esclarece, de maneira tão sintética quanto magistral - e não há razão para ponderar esse elogio - a passagem do patronato ao vicariato, bem como o motivo pelo qual os franciscanos inventam tal teoria. Ele também faz um exame do próprio vicariato no capítulo $\mathrm{X}$, enfrentando possíveis concessões em algumas bulas. Sua concepção teológico-religiosa do Estado das Índias, contida no capítulo XIV, também é luminosa. Uma reflexão sobre essas páginas, relacionada ao pensamento de Lutero, é, sem nenhuma outra qualificação possível, perturbadora $^{10}$. Finalmente, o capítulo XV contém páginas igualmente luminosas sobre a origem e os precedentes do regalismo, onde ele mesmo coloca a questão em relação com a reforma luterana.

Menos comprometidas são outras obras de síntese, como a do meu admirado mestre Sánchez Bella ${ }^{11}$, em cujos capítulos introdutório e primeiro são tratados respectivamente o regalismo e a atitude da Santa Sé. E ainda a obra de Lopetegui e Zubillaga ${ }^{12}$, já citada, na qual, ao falar sobre o vicariato, toca a visão política e exige que o estudioso do tema esteja situado no lugar e na mentalidade do momento, além de conhecer - obviamente - as instituições ${ }^{13}$.

Recentemente surgiram novos trabalhos sobre o vicariato que se relaciona como o régio patronato, devido à pena de Francisco Cantelar ${ }^{14}$. A estes podem ser acrescentadas outras obras, que foram publicadas faz tempo, que são exposições conjuntas da Igreja indiana ou do pensamento de certos autores em relação com o patronato indiano ${ }^{15}$.

9 HERA, Alberto de la. Iglesia y Corona en la América española. Madri: Mapfre, 1992.

10 Por exemplo, a excelente síntese: SCHAUB, Marianne. La réforme luthérienne: une théologie de l'absolutisme. In: GENET, Jean-Philippe; VINCENT, Bernard (coord.). État et Église dans la genèse de l'État Moderne. Bibliothèque de la Casa de Velázquez. n. 1. Madri: Casa de Velázquez, 1986. p. 187-194.

11 SÁNCHEZ BELLA, Ismael. Iglesia y Estado en la América española. 2. ed. Pamplona: EUNSA, 1991. Ver também a síntese feita por Alberto de la Hera em dois textos da obra de Pedro Borges, o cap. 5 (HERA, Alberto de la. El Patronato y el Vicariato Regio en Indias. In: BORGES, Pedro (dir.). Historia de la Iglesia en Hispanoamérica y Filipinas. v. 1. Madri: BAC, 1992. p. 63-79) e o cap. 6 (HERA, Alberto de la. El regalismo indiano. In: BORGES, Pedro. Historia de la Iglesia... p. 81-97).

12 Ver nota 2.

13 Ibidem à nota 2, p. 160 et seq.

14 CANTELAR RODRÍGUEZ, Francisco. Patronato y vicariato regio español en Indias. In: AA.VV. Derecho canónico y pastoral en los descubrimientos luso-españoles y perspectivas actuales: XX Semana Luso-Española de Derecho Canónico. Bibliotheca Salmanticensis - Estudios. n. 112. Salamanca: Universidad Pontificia de Salamanca, 1989. p. 57-102. Ver também: CANTELAR RODRÍGUEZ, Francisco. El Patronato regio de Indias en Solórzano Pereira. In: SOLÓRZANO PEREIRA, Juan de. De Indiarum Iure. Lib. III: De retentione Indiarum. Madri: CSIC, 1994. p. 193-205.

15 Assim, por exemplo, a obra citada de Lopetegui e Zubillaga, bem como as de Bruno, Ayala e Delgado, Gutiérrez de Arce e Porras Muñoz, enquanto exposições de conjunto. Sobre questões mais particulares do patronato, podem ser citados os trabalhos de Padden, Schwaller, Rodríguez Valencia, Ting Pong Lee, López Ortiz e González Zumárraga. Faço referência ao leitor quanto ao elenco bibliográfico publicado por Sánchez 


\section{EM DIREÇÃO À FORMULAÇÃO DA TEORIA VICARIAL}

1. O princípio geral do qual se deve partir é diametralmente oposto ao que o vicarialismo implica: era perfeitamente assumido pelos Reis Católicos que um leigo não poderia imiscuir-se em assuntos de disciplina eclesiástica, salvo por expressa concessão da autoridade papal.

Precisamente, a concessão das bulas Inter Caetera introduz pela primeira vez um elemento novo: a obrigação de enviar missionários que reúnam as qualidades necessárias para cumprir sua missão evangélica. Ainda que, por meio da Eximiae devotionis, os direitos dos reis de Castela fossem equiparados aos de Portugal, não por isso acreditou-se revestido o rei de poderes vicariais. É sabido que solicitou ao Papa faculdades jurisdicionais para a atividade do padre Boyl nas Antilhas. Outra coisa é que Fernando tivesse - como de fato teve - uma marcada consciência de patrono, que só viria a incrementar-se com seus sucessores. Desde a concessão do Patronato das Índias por Júlio II, as competências alcançadas inclusive na delimitação das dioceses iriam fortalecer a sua posição. Como veremos a continuação, as faculdades do rei eram suprapatronais ${ }^{16}$.

No entanto, Fernando tinha consciência de que o mandato alexandrino destinare debeatis não lhe concedia faculdades vicariais, pois quando se tratava de obter licenças ministeriais para os missionários, ou ainda de assuntos meramente espirituais, o rei acudia em cada caso a Roma ${ }^{17}$.

2. Portanto, devem ser resumidas muito brevemente as concessões outorgadas pelas bulas pontifícias que tenham relação com nosso objeto.

As bulas Inter Caetera são extremamente taxativas em relação ao dever de evangelização imposto aos reis. Isso se lhes impõe em virtude da santa obediência e se concretiza na obrigação de enviar com a devida diligência, homens honrados, tementes a Deus, doutos, peritos e especialistas, para instruir os índios na Fé católica ${ }^{18}$. O problema da Bella: SÁNCHEZ BELLA, Ismael, Historiografía de las instituciones jurídicas indianas (1945-1987). In: VÁZQUEZ DE PRADA VALLEJO, Valentín; OLÁBARRI GORTÁZAR, Ignacio (coord.). Balance de la Historiografia sobre Iberoamérica (1945-1988): Actas de las IV Conversaciones Internacionales sobre Historia (Pamplona - 10-12 marzo 1988). Pamplona: EUNSA, 1989. p. 291-345 (particularmente o apartado 5 com suas respectivas notas).

16 EGAÑA, Antonio de. La teoría del Regio Vicariato español en Indias. Roma: Università Gregoriana, 1958. cap. 1, p. 4 et seq.

17 Assim diz expressamente o padre Egaña (ibidem, p. 26).

18 Bulas Inter Caetera de 3 e 4 de maio de 1493: 9. "Et insuper, mandamus vobis in virtute sanctae obedientiae, ut, sicut etiam pollicemini, et non dubitamus pro vestra maxima devotione et regia magnanimitate vos esse facturos, ad terras ' $2^{a}$ terras firmas' et insulas praedictas, viros probos et Deum timentes, doctos, peritos et 
interpretação se apresentará depois; mas o Papado entende que os privilégios concedidos pela Santa Sé aos reis - se por acaso venham a requerer interpretação ou com ela possam vir a criar um prejuízo ou diminuição à jurisdição ou imunidade eclesiástica - devem ser interpretados pelo Papa.

É Urbano VIII quem se pronuncia dessa maneira, e em plena controvérsia sobre a obra de Solórzano. Mas, sem negar a evidência de que o Papa deseja preservar os direitos da Igreja, não é sem sentido que ele se atribua a si mesmo o direito de interpretar os privilégios concedidos. Enquanto não se produz uma declaração interpretativa papal, devem ser interpretados ad pedem litterae. Não é difícil imaginar o que aconteceria se fosse o privilegiado quem viesse a interpretar o privilégio $^{19}$. Sobre isso retornaremos mais adiante.

Consideremos o valor da bula Eximiae Devotionis quanto à possível origem do vicariato $^{20}$. É sabido que esta bula estende aos Reis Católicos os privilégios que Portugal tinha na África. Estes, concedidos por distintas bulas, abarcavam muito mais do que um simples direito patronal.

Com efeito, a Inter Caetera de Calixto III concede à Ordem de Cristo a jurisdição espiritual absoluta em terras da África. Mas esses privilégios são do tipo pessoal, como o são os concedidos aos Reis Católicos. Portanto, os privilégios concedidos aos reis portugueses também se os concedem aos castelhanos, mas, junto com o professor De la Hera, deve-se concluir que a jurisdição desta bula, materialmente contida nela, não foi buscada nem exercida ${ }^{21}$.

Recentemente foi analisada a importância da bula Piis fidelium na origem do vicariato. Esta bula outorga um título vicarial através dos reis, dadas as funções que lhes são confiadas na missão do padre Boyl: faculdade vicária de designar missionários, exercida somente uma vez e que logo caiu em desuso, ao esgotar-se o caso específico para o qual foi prevista ${ }^{22}$.

expertos, ad instruendum incolas et habitatores praefatos in Fide catholica et bonis moribus imbuendum, destinare debeatis, omnem debitam diligentiam in praemissis adhibentes".

19 Constituição de Urbano VIII, "Super praeservatione iurium Sedis Apostolicae a quibuscumque praeiudicialibus". (LETURIA, Pedro de. Antonio Lelio de Fermo y la condenación del 'De Indiarum Iure' de Solórzano Pereira. In: LETURIA, Pedro de. Relaciones entre la Santa Sede e Hispanoamérica: I. Época del Real Patronato, 1493-1800. Caracas: Sociedad Bolivariana de Venezuela, 1959. p. 394 et seq.)

20 Ver análise em: HERA, Alberto de la. Iglesia y Corona en la América española. Madri: Mapfre, 1992. p. 268 et seq.

21 No mesmo sentido: EGAÑA, Antonio de. La teoría del Regio Vicariato español en Indias. Roma: Università Gregoriana, 1958. p. 6 et seq.

22 HERA, op. cit., p. 266 et seq. Ver também, o estudo das sucessivas delegações missionais em: LETURIA, Pedro de. El regio vicariato de Indias y los comienzos de la Congregación de Propaganda. In: LETURIA, Pedro de. Relaciones entre la Santa Sede e Hispanoamérica: I. Época del Real Patronato, 1493-1800. Caracas: Sociedad Bolivariana de Venezuela, 1959. p. 108-111. 
Menção especial merece a bula - alguns a entendem como uma breve - Omnimoda de Adriano VI, outorgada em 1522, que concedia faculdades quase-episcopais aos superiores das Ordens, de maneira que se articulassem tanto os direitos do rei como os daqueles. Os superiores recebem a designação e a nomeação de seus frades para as missões, com encargos de consciência. Os religiosos podem escolher o seu próprio superior, a quem o Papa, diretamente, outorga jurisdição sobre os expedicionários, com faculdades para regular a sua vida e atividade.

Paralelamente, reconhece-se ao rei e a seu Conselho o direito de seleção, exame e veto, tanto nos termos das qualidades que devem reunir os enviados, quanto no número a ser enviado $^{23}$. Sabe-se que, quando foi sendo criada a hierarquia diocesana, os bispos consideraram excessivos os privilégios da Omnimoda. A luta entre bispos e religiosos foi um componente estritamente político da consolidação do vicariato, já que estes se dirigiram à autoridade real, considerando os reis como vigários do $\mathrm{Papa}^{24}$ - o que não impediu que o documento em questão nada falasse sobre a condição vicarial no plano espiritual dos reis da Espanha. Seriam os religiosos os encarregados de invocá-lo, porque era conveniente para seus propósitos.

Finalmente, é conveniente aludir ao precedente da Monarquia Sícula, o qual foi alegado mais de uma vez em apoio ao vicariato supostamente concedido pelo Papa. Assim, Urbano II (1088-1099) havia concedido a Rogério de Calábria ${ }^{\mathrm{b}}$ e seus sucessores o caráter de legados a latere para a Sicília. Para juristas régios, essa concessão era equivalente a um vicariato concedido aos reis leigos naquela ilha, que naturalmente reverteria para Fernando, o Católico, e seus sucessores. A controvérsia assumiu um caráter dramático com a retirada do embaixador Alcañices em 1581, levando o Papa a dizer que, se ele era Papa no resto do mundo, não teria por que não ser também na Sicília, onde ademais era um feudo da Santa $\mathrm{Sé}^{25}$. Solórzano, é claro, cuidaria de alegar esse pretenso direito em defesa de sua formulação da teoria vicarial.

É evidente que, se as distintas concessões pontifícias outorgam ao rei - no final do século XVI - faculdades para enviar missionários, atuar com os mesmos privilégios que os reis portugueses, receber dízimos das Índias, exercer o Patronato Universal (bula Universalis

23 EGAÑA, Antonio de. La teoría del Regio Vicariato español en Indias. Roma: Università Gregoriana, 1958. p. 14 et seq.

24 HERA, Alberto de la. Iglesia y Corona en la América española. Madri: Mapfre, 1992. p. 192 et seq.

b Nota de tradução: Rogerius de Altavilla (Rogério I da Sić́lia, 1031-1101) teria recebido privilégio por bula papal de executar os preceitos das autoridades supremas da Igreja, privilégio esse que também era uma obrigação de realizar as regulações papais em sua terra, na sua condição de governante secular.

25 EGAÑA, op. cit., p. 21, 53 e 118 et seq. 
Ecclesiae de Júlio II, 1508) e, conforme o caso, dividir dioceses, então se lhe haviam concedido faculdades suprapatronais que, com o tempo, ficariam reservados à Congregação de Propaganda Fide ${ }^{26}$.

3. O vicariato não foi, por óbvio, concedido pelos Papas. Entretanto, a pouco e pouco foi sendo forjada a configuração do rei como vigário apostólico nas Índias, mesmo que não tenha nascido entre elementos oficiais. Nas Índias, não havia Núncios ou Patriarcas; antes disso, os reis se opuseram tenazmente a que viessem a existir os segundos, enquanto que o Papa, aos primeiros. O que levou a que o rei a agisse muitas vezes, de fato, como um verdadeiro vigário pontifício. Vejamos como se mostra.

O criador da teoria vicarial, Pe. Focher, diria claramente: o Papa pode enviar missionários para converter os infiéis, por si mesmo ou por outro. Isso ocorre com os provinciais franciscanos e também com o próprio rei da Espanha. De fato, entende-se que os missionários que são enviados de forma imediata por este, o seriam mediatamente pelo Papa, porque quem faz algo por meio de outro é como se estivesse fazendo isso por si mesmo ${ }^{27}$.

O padre Alonso de la Veracruz, agostiniano e fiel seguidor de Focher, distingue duas personalidades do rei: uma, como senhor temporal, essencial à sua posição, e a outra, como delegado pontifício, que é per accidens. O Papa pode nomear um secular delegado para assuntos espirituais, assim como um bispo pode nomear um leigo como provedor oficial. Finalmente, como todos os infiéis são ovelhas do Papa in potentia, este pode encomendar aos Reis Católicos o ato de trazê-los para o rebanho de Cristo. De onde se supõe que o rei possa delegar as faculdades ministeriais aos religiosos, de maneira que, sendo um deles enviado pelo rei, estão ipso facto capacitados a administrar.

É aqui que Veracruz revela seu interesse pela teoria: é simplesmente uma questão de destacar que os religiosos enviados à missão pelo rei não necessitam de nenhuma licença episcopal para exercer o seu ministério ${ }^{28}$. O afirmado antes é uma simples argumentação de uma meta julgada como essencial dentro do que deve ser considerado, sem dúvida, como relações de poder entre autoridades religiosas, sendo, portanto, estritamente políticas.

Uma reviravolta no tema dá o Pe. Manuel Rodríguez em suas Quaestiones regulares; porque distingue entre delegado e vigário. O primeiro é aquele que atua em lugar de outro por

26 EGAÑA, Antonio de. La teoría del Regio Vicariato español en Indias. Roma: Università Gregoriana, 1958. p. 24.

27 Capítulo XII do "Itinerarium" de Focher, reproduzido por Egaña em: ibidem, p. 67.

28 Ibidem, p. 82 et seq. 
encargo, e não por lei. Mas o vigário é aquele que foi instituído em lugar do ausente, seja defunto ou impedido, e estes não têm jurisdição delegada, mas antes ordinária. O rei tem essa delegação - não o chama vigário - não ex lege, mas ex privilegio. Por meio do qual, vai onde todos eles vão: para que a designação de pueblos aos religiosos, feita pelos reis, há de ser entendida como efetuada pelo próprio $\mathrm{Papa}^{29}$.

O também franciscano Pe. Miranda é - no meu entender - mais claro na explicação do que significa o "vicariato indiano": os reis não atuariam nas questões espirituais das Índias por sua própria autoridade - posto que esta, por si mesma, não se estende àquelas - mas sim por delegação e comissão especial dos Romanos Pontífices, os quais, para o aumento dos fiéis, fizeram-lhes seus legados e comissários, com potestade plenária para administrar e dispor nas coisas espirituais tendentes ao fim pastoral já mencionado ${ }^{30}$.

A teoria pode levar a excessos inevitáveis, como o denunciado pelo dominicano Pe. Remesal, que indicou que até os oficiais régios se sentiam autorizados para subdelegar no que toca ao espiritual ${ }^{31}$. Obviamente, admitida a delegação pontifícia no rei, é difícil negar a subdelegação aos funcionários que exercem autoridade em seu nome.

Por fim, essa evangelização levada a cabo por meio de missionários - fato incontroverso - levou a que eles mesmos convertessem os reis em delegados ou vigários da Santa Sé. Foi criado de uma maneira interessada, como já dissemos antes e veremos na próxima seção com mais detalhes; foi aceita pela Coroa e seus órgãos de governo nas Índias e ainda foi aceita pelos bispos, em virtude da tolerância de facto que lhe outorgou a Santa Sé, mesmo que salvando os princípios.

O vicariato se apresenta como uma formulação paroxística do patronato e, para não resultar viciado em suas origens, tenta aparentar que - como ocorre com o primeiro - foi concedido pela Santa Sé. Na realidade, esta nunca o concedeu, mas teve que tolerá-lo, porque, afinal - por razões políticas - não havia outro remédio. E se distingue da regalia, por ser um direito inato da Coroa, não concedido como no caso do patronato e também do vicariato ${ }^{32}$.

29 EGAÑA, Antonio de. La teoría del Regio Vicariato español en Indias. Roma: Università Gregoriana, 1958. p. 92 et seq.

30 Ibidem, p. 96.

31 Ibidem, p. 99.

32 Esta é a conclusão que está subjacente às páginas 393 e seguintes do estudo já citado: HERA, Alberto de la. Iglesia y Corona en la América española. Madri: Mapfre, 1992. Sobre a distinção entre vicariato e regalia, ver p. 408 et seq. 


\section{ASPECTOS POLÍTICOS DA FORMULAÇÃO DA TEORIA VICARIAL}

Com o que foi dito, fica claro que os reis se consideravam patronos das Índias, por especial concessão papal. Mas essas bulas concediam algo distinto e superior ao patronato: o encargo recebido do Papa, em virtude da santa obediência, quanto à evangelização das Índias. Mas até o final do século XVI, não tiveram consciência moral do vicariato, nem invocaram outro título diferente ao de patrono. O qual não obsta a que os privilégios pontifícios, juntamente com suas próprias intervenções, fossem o fundamento da teoria vicarial ${ }^{33}$.

Porque, de fato, sua formulação não foi uma invenção gratuita dos religiosos. Estes se apoiaram no que havia para fundamentar juridicamente algo que não havia sido concedido.

1. O precursor, como todo o mundo sabe, é o franciscano Fr. Juan de Focher ${ }^{34}$. Não vamos nos ocupar de sua vida, nem de outras questões gerais, mas nos ater ao que realmente interessa neste apartado.

Focher adota, desde o primeiro momento, uma ótica conducente a seus fins, a saber, que os religiosos enviados pelo Papa, ou por outro príncipe cristão que dele tenha recebido tal faculdade, são pessoas públicas. O Papa pode comissionar a um eclesiástico ou um secular para enviar missionários, de modo que, àqueles que são enviados, dá igual que o sejam pelo rei ou pelo pontífice. No entanto, a concessão de Alexandre VI converte ao rei como seu vigário unicamente quanto ao envio de missionários.

Sabe-se que a obra de Focher começa a partir do momento em que os frades, em virtude da Omnimoda, estavam isentos da jurisdição episcopal e capacitados para exercer qualquer ato ministerial, exceto aqueles que requerem consagração episcopal, na distância de duas dietas do ponto em que se encontre o bispo ou seu delegado. Com o estabelecimento da hierarquia episcopal, e surgidos os primeiros atritos, os religiosos se ocuparam de confirmar e acrescentar as concessões de Adriano VI. Por sua parte, os bispos expressaram seu desconforto em uma carta coletiva ao Imperador. Em 1539, a junta de bispos (Zumárraga, López de Zárate e Vasco de Quiroga) chegou a um acordo com os superiores dos religiosos,

33 EGAÑA, Antonio de. La teoría del Regio Vicariato español en Indias. Roma: Università Gregoriana, 1958. p. 50 et seq.

34 Sobre ele têm-se ocupado, entre outros, LETURIA, Pedro de. El regio vicariato de Indias y los comienzos de la Congregación de Propaganda. In: LETURIA, Pedro de. Relaciones entre la Santa Sede e Hispanoamérica: I. Época del Real Patronato, 1493-1800. Caracas: Sociedad Bolivariana de Venezuela, 1959. p. 107-122.; EGAÑA, op. cit., p. 60-76.; LOPETEGUI, León; ZUBILLAGA, Félix. Historia de la Iglesia en la América española. v. I. Madri: BAC, 1965. p. 144-148. 
para que estes ficassem sujeitos à sua jurisdição, embora ficassem convalidados os atos exercidos em virtude dos privilégios concedidos às Ordens.

Essa composição foi um exercício de política conciliatória. Mas os religiosos - vendo que se lhes arrebataram suas fundações, e que se lhes proibia conhecer em causas matrimoniais, inclusive em suas paróquias sem contar com o diocesano - tomaram a defensiva, acudindo ao rei em defesa dos privilégios de Leão X e Adriano VI. Dessa maneira, duas frentes foram formadas: bispos e clero secular, por uma parte, e regulares e Coroa, por outra.

O rei mandou guardar os privilégios e isenções dos religiosos sem fazer novidade alguma (Real Cédula de 30 de março de 1557), mas, enquanto isso, Paulo IV, pela bula $E x$ clementi Sedis Apostolicae, confirmava aos franciscanos os privilégios outorgados por seus antecessores, pelos reis e imperadores, segundo a interpretação mais favorável. E os dominicanos conseguiram o mesmo.

Obviamente, Focher não deixa de registrar a importância da confirmação "na inteligência mais favorável" dos privilégios emanados das potestades antes mencionadas. Mas vai além: formalmente entende que Paulo IV aprova as ordens dadas pela Coroa como se fossem emanadas desde a Santa Sé. E, para o futuro, virtualmente, por essa mesma aceitação, faculta ao rei dar estatutos à Igreja "indiana", cuja execução é confiada aos mendicantes. O rei, segundo Focher, pode legislar como vigário, com igual valor que o Papa; e os religiosos se reservam o interpretar essas faculdades no sentido de que lhes seja mais favorável.

2. Mas, com o aporte de Focher, ainda se estava longe de dizer-se a última palavra sobre o vicariato. Com a continuação da luta em termos políticos, novos aportes se seguiriam, fortalecendo a posição dos reis, justamente porque era favorável aos interesses dos religiosos.

O Pe. Alonso de la Veracruz, agostiniano e contemporâneo de Focher, reagiu quando, em 1565, Pio V, com a bula In Principis Apostolorum Sede, revogou todos os privilégios concedidos aos mendicantes que fossem contrários ao Concílio de Trento, a fim de submeter à jurisdição episcopal a cura das almas e a administração dos sacramentos. De fato, apresentou um memorial ao rei solicitando que se negociasse a revogação de tais disposições com o Papa, para que voltassem a ter vigência os privilégios concedidos às Índias.

Caso esse papel fosse esquecido, Veracruz redigiu um elenco das faculdades concedidas pelo Papa às Ordens mendicantes, que enviou ao Conselho das Índias, onde, com relação a essas questões, nada passava desapercebido. 
Não precisava Veracruz ${ }^{35}$ mais que a Inter Caetera para forjar a sua teoria, o que supõe uma radicalização de seus próprios fundamentos - diríamos que por uma tática defensiva dos interesses dos isentos. Para ele, a concessão alexandrina é, pura e simplesmente, a concessão aos reis da condição de vigários do Papa ${ }^{36}$. Poder-se-ia pensar que a concessão vicarial não se estende a outra coisa que o envio de missionários para as missões que lhes são próprias. Mas não: Veracruz faz uma interpretação extensiva, baseada no princípio jurídico de que "quem pode mais, pode menos"; e, portanto, os reis, sendo investidos na faculdade de enviar missionários, têm atribuições suficientes para o que for necessário para a finalidade do envio missional.

E chega onde queria: o rei pode declarar que os regulares, com direito exclusivo, são ministros dos índios e que, por sobre qualquer outra jurisdição, podem administrar sacramentos, edificar conventos sem a licença do Bispo e até contra o seu consentimento.

Em suas propostas extremadas - política pura e dura - Veracruz compromete a autoridade régia de forma total: os reis podem concretizar, assim como o Papa, todos os detalhes da vida missional, já que "data est regibus potestas providendi, et sub obedientia iniunctum". E, apenas por precaução, adota duas cautelas: uma, invocar o privilégio da concessão papal, ao tratar do exercício até o detalhe de suas faculdades, com o perigo da condenação eterna. A outra, designar aos reis, simplesmente, patronos.

Creio que se pode qualificar abertamente como perversão o aporte doutrinário do agostiniano, pois coloca os reis, de facto, como chefes da Igreja "indiana", e com um aroma de protestantismo que deve fazê-los meditar em sua heterodoxia. Para não deixar de lado os bispos, sucessores dos apóstolos, entende que a provisão de missionários é incumbência primeira e principalmente do rei, e, de forma subsidiária, dos bispos: tornando-os subsidiários do rei. Não creio que seja pertinente fazer maiores comentários ${ }^{37}$.

35 Ver: EGAÑA, Antonio de. La teoría del Regio Vicariato español en Indias. Roma: Università Gregoriana, 1958. p. 78-87; LETURIA, Pedro de. El regio vicariato de Indias y los comienzos de la Congregación de Propaganda. In: LETURIA, Pedro de. Relaciones entre la Santa Sede e Hispanoamérica: I. Época del Real Patronato, 1493-1800. Caracas: Sociedad Bolivariana de Venezuela, 1959. p. 125 et seq.

36 Merece ser transcrito literalmente uma asserção tão categórica, formulada de modo apodítico: "Concessit Summus Pontifex 'Alejandro VI' Reges Catholicos et suos legitimos sucessores, quales nunc sunt Philippus rex Hispaniarum et filius eius legitimus, princeps Carolus, facit suos legatos et praebet ipsis ius et facultatem eligendi tales ministros idoneos et mittendi eos pro conversione et instructione infidelium, et sic perinde, est quod tales mittantur a Summo Pontifice immediate, vel mittantur ab ipsis regibus..." (VERACRUZ apud EGAÑA, op. cit., p. 79).

37 Assim é dito: "Et ad Episcopos tamen 'spectat' quod tunc ex regia cornmissione eis fuerit concessum, nisi Summus Pontifex, qui ipsis regibus negotium praedelegavit, aliud provideat" (VERACRUZ apud EGAÑA, Antonio de. La teoría del Regio Vicariato español en Indias. Roma: Università Gregoriana, 1958. p. 81). Devese acrescentar que o poder papal de fornecer outra coisa não passa de retórica, pois, ao fazê-lo, entraria em conflito com os direitos anteriormente concedidos e exercidos pelos reis, que negariam qualquer prejuízo. 
Como um bom escolástico, Veracruz ao final aborda a questão - tocante ao foro interno - de se um religioso, que administra somente com a licença do rei, o faz de maneira tão válida e lícita como se tivesse a licença do pároco. E sua opinião é que sim, porque o Papa é o primeiro e imediato prelado, e o rei, delegado pontifício - mesmo que per accidens - pode delegar faculdades ministeriais aos religiosos; além disso, basta que sejam enviados pelo rei para que sejam considerados ipso facto capacitados para administrar. E, enquanto durar o motivo final da missão, a delegação papal dura.

Nem o Concílio de Trento, nem os bispos podem fazer nada para alterar esse estado de coisas: não devem reclamar, porque o mesmo rei que beneficia os religiosos, lhes deu a mitra.

Se o Pe. Alonso de la Veracruz confessou ter ficado em trevas após a morte do Fr. Juan Bautista, tentou e conseguiu escapar delas, trazendo um brilho ofuscante ao vicariato indiano, sobre o qual, se estava convencido, outros setores não o compartiam de todo, mesmo que estivessem bem dispostos quanto aos religiosos. Filipe II, por solicitação dos agostinianos, obteve do enérgico Pio V o breve Exponi nobis (24 de março de 1567) a ele dirigido, pelo qual se autorizava aos religiosos a atuação como párocos nas Índias sem a licença dos Ordinários, tal como era o costume, e proibindo toda inovação.

Mas se nosso autor chegou a apoiar-se no rei da maneira que foi relatada, não se pode deixar de reiterar que isso foi na medida em que o vicariato não prejudicasse os interesses das Religiões. Assim, em 1574, escreveu ao presidente do Conselho das Índias, protestando contra o mandato régio de que os superiores eleitos se apresentassem às autoridades civis, isso porque, segundo ele, as Religiões não dependem da potestade secular.

São os inconvenientes de cair diretamente no jogo político. Todo o rigor metodológico, com o qual expõe sua teoria, vem abaixo quando se atreve a cogitar, sem o menor rubor, semelhante inconsequência. Há aí outra perversão. Se o rei é delegado do Papa, o é para tudo, não apenas para apoiar as Religiões contra os bispos. Creio que essa parcialidade do agostiniano deve ser destacada, o que faz vacilar grandemente a luz que lançou sobre o vicariato depois das trevas em que lhe deixou a morte de Pe. Juan de Focher.

3. Embora outros religiosos se ocupassem do tema, vamos nos deter por um momento no aporte do franciscano Pe. Manuel Rodríguez, que publica a sua obra Quaestiones regulares em $1598^{38}$.

38 LETURIA, Pedro de. El regio vicariato de Indias y los comienzos de la Congregación de Propaganda. In: LETURIA, Pedro de. Relaciones entre la Santa Sede e Hispanoamérica: I. Época del Real Patronato, 1493-1800. Caracas: Sociedad Bolivariana de Venezuela, 1959. p. 131-136.; EGAÑA, Antonio de. La teoría del Regio 
É importante notar que o sucessor de São Pio V, Gregório XIII, emitiu em 1573 o breve In tanta rerum, abolindo as concessões anteriores, quando não se conformassem ao Concílio de Trento, ainda que sem se referir aos privilégios de seu antecessor, nem ao monarca espanhol. Em 1585, o III Concílio do México comunicou essa novidade aos mendicantes, que não se sentiram aludidos pelo breve, já que, ao não serem citadas as concessões feitas ao rei, deveriam ser entendidas como vigentes. Feita representação ao rei que foi quem resolveu, conciliador: os religiosos continuariam em suas doutrinas como até então, mas os bispos deveriam visitar as igrejas das doutrinas, deixando a visita de moribus et $v i t a$ - como estabelecia o tridentino - aos superiores das Religiões.

Por outro lado, o arcebispo de Lima, São Toribio de Mogrovejo, pediu a Roma (15851586) o esclarecimento de seus famosos 37 pontos, um dos quais, o 23, referia-se expressamente à vigência do breve de São Pio V, sua revogação por Gregório XIII e a necessidade de que os mendicantes fossem examinados pelos bispos quanto à administração sacramental. A resposta foi precisa: o Exponi nobis foi revogado e os regulares tiveram que ser examinados pelos bispos.

O Concílio de Lima de 1591 comunicou esta resolução aos religiosos, que fizeram exatamente o mesmo que no caso do México: como o breve de São Pio V havia sido concedido ao rei enquanto patrono das Índias, não poderia ser revogado sem ser este citado e ouvido. A batalha foi vencida novamente pelos religiosos, uma vez que Gregório XIV confirmou o breve piano, e Clemente VIII estenderia as isenções em 1592 a todos os mendicantes do Peru e, posteriormente, aos jesuítas em 1598.

Para Rodríguez, o rei é um delegado, que age por comissão e não por lei. Portanto, ele pode designar missionários para os índios sem a licença dos bispos, pois, tendo a autoridade delegada do Papa, é como se o mesmo pontífice o fizesse. É a afirmação de Veracruz. Mas, se por acaso os bispos protestassem porque sua autoridade lhes é tirada, acrescenta que o Papa pode enviar missionários ao mundo inteiro, sem o consentimento dos bispos, e esse é a potestade conferida aos reis ${ }^{39}$.

Descendo ao terreno prático e para deixar a salvo os religiosos de qualquer intromissão episcopal, sustenta que qualquer privilégio impetrado ao Papa, que afete o

Vicariato español en Indias. Roma: Università Gregoriana, 1958. p. 89-95.

39 "Et si dixeris, quomodo Papa aufert Episcopis suam auctoritatem, respondeo quod Papa non aufert eam Episcopis, qui 'quia?, melius' potest ubique terrarum ministros praeficere pro salute animarum suarum sine consensu ordinariorum ... Et han potestatem praeficiendi ministros, pro salute animarum, potest Papa commitere quibus sibi visum fuerit, et sic commitit regibus Hispaniae”. Citado por: EGAÑA, Antonio de. La teoría del Regio Vicariato español en Indias. Roma: Università Gregoriana, 1958. p. 93. 
governo espiritual das Índias, não pode ser executado sem a aprovação do Conselho das Índias. E os bispos e metropolitanos não podem publicar as atas de um concílio provincial ou sinodal sem o passe régio "ne perturbent seu impediant conversionem indorum".

E, para deixar a salvo os religiosos da tutela excessiva da parte do rei, estabelece que, se um religioso tiver permissão por escrito de seu Geral para fazer visita à Nueva España, sendo conveniente ao regime ou o governo da Ordem, tais cartas terão vigor inclusive ainda que não tenham sido registradas pelo Conselho, tanto no foro interno como no externo. $\mathrm{O}$ que equivale dizer, com suavidade, que são válidas mesmo que o Conselho negue o passe para tal documento.

Os religiosos, então, admitem o vicariato enquanto os beneficia, mas não enquanto os prejudica.

\section{A CONSAgRaÇão POlítica da TEORIA POR JUAN DE SOLÓRZANO PEREIRA}

Para um indianista, não há necessidade de apresentação desse jurista, o mais exímio de todos os que, no âmbito civil, escreveram sobre as Índias. A formulação que nos interessa está em sua obra De indiarum Iure, publicada em 1629, embora, como se sabe, sua Política Indiana, publicada em 1647, resumisse em parte seu trabalho anterior e parcialmente o corrigisse e o acrescentasse.

1. Comecemos assinalando que o patronato indiano ${ }^{40}$ não é uma concessão graciosa, mas onerosa, da qual nascem múltiplos direitos do rei sobre a Igreja indiana. Devido a esse caráter, não é revogado pelo tridentino. Embora, na sequência, acrescente que, se fosse expressamente revogado, seria necessário pleitear sobre, com base nos documentos concessórios e no uso constante, que é no direito o título legítimo de seu exercício. $\mathrm{O}$ patronato é de natureza laical, tanto por ser exercido pelos leigos, quanto por se basear em bens seculares dados à Igreja.

Esse patronato, uma vez incorporado à Coroa, é inalienável, nem mesmo pela vontade do rei - ou seja, passa de concessão à regalia. Dessa qualidade, para Solórzano, derivam quatro direitos: a defesa de todos os assuntos relacionados a ele, a apresentação de quaisquer ofícios e benefícios eclesiásticos, o honorífico de colocar o escudo real em suas fundações 40 Ver a síntese de Egaña (EGAÑA, Antonio de. La teoría del Regio Vicariato español en Indias. Roma: Università Gregoriana, 1958. p. 109-125). 
patronais. $\mathrm{O}$ direito de demarcar dioceses não deriva do patronato, mas de outra concessão pontifícia, mas sim o juramento de fidelidade dos prelados.

2. A condição dos vigários apostólicos que os reis têm baseia-se, de acordo com a síntese de Egaña ${ }^{41}$, em quatro apartados: 1) nos leigos, não há defeito na capacidade de entender quanto a pessoas e causas eclesiásticas e espirituais; 2) os reis são vigários papais fora das Índias, como por exemplo na Sicília, onde são legados a latere; 3 ) os reis são vigários do Papa nas Índias e 4) desse vicariato, para o rei se derivam certos direitos.

Deixando de lado os dois primeiros apartados, focaremos no terceiro e no quarto. Para Solórzano, a bula Inter Caetera e as demais os tornam vigários do Sumo Pontífice, tanto em privilégios e funções espirituais, quanto em outras coisas necessárias para exercê-las. Portanto, o vicariato tem uma origem pontifícia indubitável, não se tratando de um direito inato ou regalia.

Como princípio geral, os reis podem entender em tudo o que é necessário para a conversão dos índios. Do qual se derivam amplíssimas faculdades que atribui ao monarca: enviar missionários, examinar causas criminais contra clérigos e os castigar com o desterro e revogação de seu destino; o direito exclusivo de fundar igrejas e conventos, tanto pelo patronato quanto pelo vicariato; para aprovar as patentes dos comissários e vigários regulares; para ordenar que os cabildos, em sede vacante, entreguem a jurisdição ao bispo eleito antes mesmo de receber as bulas papais; para designar cidades (pueblos) aos regulares para o exercício de seu ministério; não permitir que a jurisdição do núncio da Espanha se estenda às Índias, tanto em virtude do patronato quanto do vicariato.

Se bem que Solórzano enumera essas atribuições de certa maneira implícita nos tratadistas religiosos, prescinde completamente dos interesses deles, para declarar unicamente os interesses e direitos do rei. Por essa razão, afasta-se dos teólogos que defendem as isenções dos religiosos, simplesmente porque não lhe interessa. E não lhe interessa porque defende a sujeição destes, enquanto párocos e responsáveis por doutrinas, aos bispos.

Para Solórzano, os direitos patronais são suficientes para defender as ações do rei nas Índias. Mas como a teoria vicarial não o repugna em absoluto, desde que seja conveniente a tais fins, e os religiosos lhe tenham dado já feita, não tem inconveniente em admiti-la e invocá-la ali onde o fundamento patronal pudesse não ser suficiente. Em outras palavras, atua por pura conveniência política.

41 EGAÑA, Antonio de. La teoría del Regio Vicariato español en Indias. Roma: Università Gregoriana, 1958. p. 114 et seq. 
Ocorre, como Leturia ${ }^{42}$ descreve com maestria, que Solórzano converte a parcialidade vicarialista dos religiosos - em si mesma política - em outra parcialidade política mais grandiosa, mas absolutamente contrária aos primeiros: trata-se da política e da razão de Estado, que deixa a árvore, mas que o despoja de todos os seus frutos.

\section{A REPROVAÇÃO DA TEORIA VICARIAL}

Deixaremos, por enquanto, a reação da Congregação de Propaganda Fide sobre a questão vicarial, porque agora estamos interessados em focar no que os outros religiosos contrários à teoria pensam, não tanto em saber por que a desaprovam, mas se não há também uma opção política em sua própria desaprovação.

Desde a época de Filipe II, a Coroa mudou de tática, começando a favorecer o clero secular em detrimento do regular ${ }^{43}$, entregando as paróquias ao primeiro e sujeitando o segundo ao exame, visita canônica e vigilância dos bispos. Isso levará a outra reação pendular de alguns religiosos, que buscarão juntar-se ao papado, contra os bispos e o rei.

Em 1638, os agostinianos protestaram na Santa Sé sobre as cédulas que os sujeitavam aos ordinários - sujeição que, diga-se de passagem, foi encontrada pela Congregação de Propaganda Fide como completamente em conformidade com o tridentino.

Desde os primeiros trinta anos do século XVII, encontramos alguns religiosos antivicarialistas, que trabalham à margem ou abertamente contra a obediência a seus superiores. Assim foi o franciscano Pe. Diego de Ibáñez, que chegou em Madri em 1630, após as diferenças que surgiram desde 1622 entre os religiosos e o vice-rei do México, Rodrigo Pacheco, e o bispo de Oaxaca, Juan de Boórques, os quais buscaram efetuar a nova política e submeter os religiosos ao bispo. Ibáñez não conseguiu nada na Espanha - isso porque a nova orientação não era discutida por ninguém, chegando a que o expulsassem do Conselho das Índias.

Cinco anos depois, em 1635, pôde ir a Roma, presumivelmente bastante indignado, tanto pelo tratamento pessoal que recebeu quanto pela pouca consideração pelas liberdades dos isentos que havia encontrado na Corte. Sua viagem foi cheia de peripécias, desde a

42 LETURIA, Pedro de. El regio vicariato de Indias y los comienzos de la Congregación de Propaganda. In: LETURIA, Pedro de. Relaciones entre la Santa Sede e Hispanoamérica: I. Época del Real Patronato, 1493-1800. Caracas: Sociedad Bolivariana de Venezuela, 1959. p. 143-145.

43 Ver: EGAÑA, Antonio de. La teoría del Regio Vicariato español en Indias. Roma: Università Gregoriana, 1958. p. 194-202. 
expulsão até a prisão, ainda que no final tenha conseguido entregar um memorial ao prefeito da Congregação, Barberini ${ }^{44}$.

Entendo que esses detalhes pessoais ajudam a entender melhor a reação posterior de Ibáñez, que foi a Roma aturdido pelo despeito, como também o faria Lelio de Fermo. Sem essa nota comum, parece que essas atitudes visceralmente contrárias ao vicariato não podem ser explicadas corretamente.

Ibáñez pensa que o rei retém seu patronato das Índias com um título não justo; que os conselheiros das Índias se intrometem de forma indecente nos assuntos eclesiásticos e que é falso que o rei seja o delegado do Papa.

Cai Ibáñez na mais baixa vulgaridade jurídica ao expor os seus argumentos: duvida da autenticidade da bula alexandrina; entende que o Papa não pode retirar de seu domínio os senhores indígenas; ignora a concessão de Júlio II; sustenta que as fundações do rei não lhe pertencem, mas sim ao dono do solo e, finalmente, que os edifícios religiosos foram fundados por estes, com esmolas de particulares; e o rei, embora tenha ajudado de alguma forma, não pode dispor em favor do clero secular contra o regular.

Ele reclama que os bispos vão aos tribunais reais contra os religiosos, violando sua condição de isentos, chegando algum do México a excomungar um guardião por Real cédula, como se fosse uma bula.

Não sem certa lógica, argumenta contra a teoria vicarial - sujeitando-a às palavras expressas de Alexandre $\mathrm{VI}^{45}$ - e para neutralizar esse estado de coisas tão admitido, não encontra outra solução senão uma declaração formal e explícita do Papa no sentido de que o rei não é um delegado pontifício nas Índias, mas antes apenas tem a incumbência do envio de missionários para instruir os índios na Fé católica. Obviamente, isso era esperar demais do Papa, como também da diplomacia vaticana, muito mais sutil e política do que as toscas teses do Pe. Ibáñez.

No final do século, mais relatórios negativos chegam a Roma sobre as ações da Coroa e dos religiosos na Igreja das Índias. Assim, em 1684 - no sentido de que todos os males se encontram no fato de que os religiosos sejam párocos, cujos superiores não hesitam em

44 EGAÑA, Antonio de. La teoría del Regio Vicariato español en Indias. Roma: Università Gregoriana, 1958. p. 198 et seq.

45 “...ex istis ergo verbis assentantes fundamenta desumunt ad asserendum, quod Rex Catholicus Hispaniarum sit in Indiis Pontificis delegatus. Sed in utroque iure peritis quasi ridiculum esse videtur, quia istorum virtute verborum, solum concedit regi potestas destinandi viros probos ad instruendos incolas Indiarum, quasi habentes portus maris, navigalia et alia quaelibet necessaria ad mittendum vel destinandum; et quantum ad hoc, destinare scilicet et mittere, verum esto quod Pontificis auctoritate facit. Sed quae convenientia haec, vel quae similitudo aut forma, cum potestate judicis delegati?". Citado por: EGAÑA, op. cit., p. 201. 
subornar os oficiais régios para que não se oponham à sua designação. Os religiosos assim enviados, em muitos casos, estão manchados de escândalos de sodomia, heresia, sendo vagabundos e exploradores dos índios ${ }^{46}$. Isso motivou a que a Congregação - com a posterior aprovação do Papa (1684) - ordenasse o cardeal Millino a que apresentasse ao rei a demanda de que os párocos regulares deveriam submeter-se aos bispos, onerando seriamente a consciência do $\mathrm{rei}^{47}$.

Em resumo, os religiosos pareciam corrompidos em seu trabalho apostólico. Era conveniente ao rei a sua sujeição por alguns motivos, ao Papa igualmente por outros. E, no meio disso, os religiosos que, depois de renderem o jogo ao primeiro, fizeram-no com igual dedicação ao segundo.

\section{RECAPITULAÇÃO DO CARÁTER PERVERSO DA TEORIA VICARIAL}

O oportunismo de Pe. Alonso de Veracruz já foi citado, quando formulou a teoria vicarial com força total e, ao mesmo tempo, afirmou que as Religiões não dependem da potestade secular. E também a Rodríguez, que apela ao Conselho das Índias no que beneficia os religiosos, ao mesmo tempo que invoca suas isenções papais contra este. Sabemos que, na primeira metade do século XVII, parte dos religiosos abandonou e atacou a teoria; por outro lado, alguns bispos passam ao seu campo, isso porque o rei os apoia em que venham a entregar as suas paróquias aos seculares e em que os regulares tenham que submeter-se à jurisdição episcopal.

Mas não devemos nos enganar: no fundo, todos os religiosos concordam em apoiá-la quando é do seu interesse, e em atacá-la quando de sua aplicação podem derivar-se consequências prejudiciais da imunidade conventual ${ }^{48}$.

Bem, os juristas e políticos régios aceitaram de bom grado o trabalho dos religiosos, mas estavam decididos a entregar aos seculares os curados e as doutrinas que já se estabeleceram. E Solórzano, um tanto cinicamente, chega ao ponto de dizer que os religiosos

46 Assim ocorre na relação feita em Roma pelo Pe. Juan Bautista Goggi, de inclinação suspeitosamente monetária. Também a do bispo de Guatemala, Juan Ortega Montañés, de 1681; do de Quito, Alfonso de la Peña Montenegro, de 1670; dos de Santa Marta e de Cartagena, de 1678 (EGAÑ, Antonio de. La teoría del Regio Vicariato español en Indias. Roma: Università Gregoriana, 1958. p. 209 et seq.).

47 Ibidem, p. 212.

48 Ibidem, p. 215 et seq. 
atuam como vigários dos clérigos, sem que possam alegar propriedade ou posse contra a vontade régia de devolver aqueles aos seculares ${ }^{49}$.

A Coroa foi submetendo cada vez mais os religiosos, aos quais, para dizer de alguma forma, foram vendo o vicariato se escapar de suas mãos. Começaram a jogar naquele terreno por pura conveniência política e foram derrotados no mesmo terreno, mas justo pelo rei, cuja posição eles haviam tanto contribuído para exaltar. Era a história do "caçador caçado".

Provavelmente agora, poderá compreender o leitor por que razão se falou na introdução das duas primeiras perversões na teoria: sua origem, que não tratava da melhor evangelização, mas antes de conservar os privilégios dos religiosos; e sua assunção pela Coroa por meio de seus juristas, para os quais o que importavam, antes de mais nada, eram os direitos do rei frente aos do Papa, e, por suposto, frente aos de quaisquer pessoas ou instituições eclesiásticas.

\section{ATITUDE DA SANTA SÉ}

Entenderemos, sob o termo Santa Sé, tanto o próprio pontífice como as Congregações romanas. Seguindo com a linha metodológica deste estudo, não vamos abordar detalhadamente toda essa questão - que, por outro lado, possui excelentes sínteses ${ }^{50}$ - mas nos fixaremos nos componentes mais políticos dessa atitude, geralmente negativa.

Antes de tudo, é necessário fazer uma matização. Assim como para a Coroa, a evangelização dos índios é a razão última da atitude da Santa Sé em relação ao Vicariato. O rei entende que se evangelizará melhor atuando como se atua, sob seu controle. Por sua vez, Roma entende que a evangelização é uma tarefa pastoral de índole espiritual, e que o rei não pode dispor desta a não ser dentro das estritas margens concedidas pela Santa Sé. Isto é, a evangelização é a última razão, mas há outras mais próximas.

49 De Indiarum Iure, tomo II, lib. III, cap. 16, n. 30: "Quod sit ut religiosi, cum talia beneficia non solum precario, sed, ut ita loquar, vicario nomine, hoc est, tamquam vicarii clericorum susceperint, nullum ius in earum proprietate, immo nec possessione praetendere possint, nec ullam iniuriam allegare vel praescriptionem obiicere, si ex regis voluntate ad saeculares clericos devolvantur". Cit. por: LETURIA, Pedro de. El regio vicariato de Indias y los comienzos de la Congregación de Propaganda. In: LETURIA, Pedro de. Relaciones entre la Santa Sede e Hispanoamérica: I. Época del Real Patronato, 1493-1800. Caracas: Sociedad Bolivariana de Venezuela, 1959. p. 139.

50 Basta referir-se a: SÁNCHEZ BELLA, Ismael. Iglesia y Estado en la América española. 2. ed. Pamplona: EUNSA, 1991. p. 55-106. Sobre a atitude da Congregação de Propaganda Fide, ver: LETURIA, Pedro de. El regio vicariato de Indias y los comienzos de la Congregación de Propaganda. In: LETURIA, Pedro de. Relaciones entre la Santa Sede e Hispanoamérica: I. Época del Real Patronato, 1493-1800. Caracas: Sociedad Bolivariana de Venezuela, 1959. p. 139-152; EGAÑA, Antonio de. La teoría del Regio Vicariato español en Indias. Roma: Università Gregoriana, 1958. p. 174-216 (cap. 6). 
E estas, que se dão por ambas partes, nada mais são do que a conservação, aumento ou recuperação das respectivas jurisdições. Por essa razão, envolvem-se em uma batalha essencialmente política, onde a doutrina é posta a serviço desse objetivo. Já não se trata mais das contribuições dos religiosos, diríamos de primeiro nível, mas do uso da teoria já assumida pela Coroa e considerada pela Santa Sé como uma questão de Estado. Os seus inventores agora ficam obnubilados, importando bem pouco. Somente Lelio brilhará com sua própria luz, porque não deixa de ser uma arma política a ser utilizada pela Santa Sé, por meio da Congregação do Índice, para contrapor o aporte de Solórzano, que na Espanha se considera definitivo. Vamos ver tudo isso.

1. A Igreja de Roma não tinha meios para assegurar por si mesma a evangelização: isso era sabido por Alexandre VI, que se aproveitou da concessão das Inter Caetera para ordenar o envio de missionários. Por essa razão, não seriam de estranhar atitudes contemporizadoras, como a observada por São Pio V, que, fundado nos cânones tridentinos para controlar a intromissão das monarquias católicas nos assuntos eclesiásticos, no entanto, teve que contemporizar, apoiando-se nas mesmas potências na luta contra o elemento turco e contra a reforma luterana ${ }^{51}$.

Basta mencionar, por exemplo, que quando em 1567 foram revalidadas as cartas fundacionais de Pio V do Bispado de La Imperial, outorga-se a Filipe II a possibilidade de variar os limites. Mas no ano seguinte, quando o Papa Peretti vai erigir o bispado de Córdoba del Tucumán, concede ao rei o direito de fixar os limites, mas dentro de certas margens nesta vez, reservando-se o Papa qualquer mudança posterior.

Ainda que esteja fora do âmbito temporal deste estudo, não posso deixar de mencionar - por simpatia para com o personagem, na linha das contemporizações da Santa Sé - a citação, também elogiosa, feita da obra de Frasso pelo cardeal Lambertini, secretário da congregação do Concílio em $1722^{52}$.

A obra de Frasso foi incluída no Index em 1688, pelo qual não deixa ser reveladora essa citação de que Roma, quando pôde, fugiu do confronto para usar, como só ela soube fazer, da diplomacia.

51 EGAÑA, Antonio de. La teoría del Regio Vicariato español en Indias. Roma: Università Gregoriana, 1958. p. 18 et seq.

52 "Praeter autem docte et copiose ab informantibus allata, ponderari meretur auctoritas Frassi, auctoris hispani, et qui fiscalis munere in Tribunalibus Regni laudabiliter functus est, ille enim in suo Tractatu de Regio Patronatu Indiarum ... testatur breve suspensivum Urbani VIII non fuisse extensum ad Indias, et ex posterioribus eiusdem Pontificis brevibus, bullam Gregorii XV esse in praxi et usu receptum in Regnis Hispaniarum". Citado por: EGAÑA, op. cit., p. 222. 
2. Mas o normal é que a Santa Sé não contemporize, ou o faça a níveis mínimos e quando não tem mais remédio. Isso ocorre com a condenação da obra de Solórzano. Mas inclusive na escolha deste autor, houve uma seleção estratégica: não foram condenados os escritos dos religiosos que estávamos citando - e que foram os verdadeiros inventores da teoria, precisamente por sua condição de religiosos ou pela menor influência que tiveram no âmbito secular ${ }^{53}$. Embora não fosse o único, Solórzano foi objeto de tratamento especial, justamente por ser o autor mais importante.

No entanto, foram condenadas previamente as obras de Jerónimo de Ceballos e de Salgado de Somoza em 1624 e 1628. Portanto, a obra de Solórzano chegou em um momento perfeito para receber a mais severa censura da Santa Sé.

Vejamos como foi produzida essa condenação, mas primeiro, apresentaremos alguns dados sobre quem a preparou, Antonio Lelio de Fermo ${ }^{54}$. Nascera naquela cidade em 1584. Estivera duas vezes em Madri com o cargo de fiscal da nunciatura entre 1621 e 1623. Mas, no exercício de seu cargo, os dois núncios com quem trabalhou não o apoiaram nas questões de jurisdição e regalismo, nas quais teve que intervir e nas quais utilizava, para submeter o rei, o seu conhecimento do direito e a ameaça de excomunhões. Fracassou, pois, e deixou a Corte no início de 1623, com destino a Roma, onde permaneceria até sua morte, ocorrida em 1655. Entrou na Congregação do Índice em uma data indeterminada, mas que foi depois de 1624.

Lelio, como diz Leturia, era muito tosco e retilíneo para a ação diplomática, muito pontifício na defesa das prerrogativas papais, e fustigava infatigavelmente os abusos dos togados de Madri, a quem os chama ironicamente de $i$ regii.

A vida de Lelio na Espanha foi de amargura, embora sua posição como coletor lhe permitisse aumentar seu próprio pecúlio, talvez demais, como diz o núncio Di Sangro ${ }^{55}$. Sua intervenção no famoso caso Covarrubias, provedor e juiz ordinário do arcebispado de Sevilha, foi estudada ${ }^{56}$ - de onde só cabe dizer aqui que os bispos e funcionários reais fugiram dele como de uma peste, e o Conselho de Castela, em 1622, desprezou sua argumentação no recurso de força interposto pelo próprio Covarrubias, ao que deu a razão. Em 1623, o núncio

53 Esta última disjuntiva de Egaña (EGAÑA, Antonio de. La teoría del Regio Vicariato español en Indias. Roma: Università Gregoriana, 1958. p. 126) me parece totalmente exagerada, e constitui o exemplo de que quer deixar a salvo a Roma, sem chegar ao verdadeiro fundo da questão, coisa que, por outra parte, permitem suficientemente os dados aportados em sua excelente obra.

54 LETURIA, Pedro de. Antonio Lelio de Fermo y la condenación del 'De Indiarum Iure' de Solórzano Pereira. In: LETURIA, Pedro de. Relaciones entre la Santa Sede e Hispanoamérica: I. Época del Real Patronato, 14931800. Caracas: Sociedad Bolivariana de Venezuela, 1959. p. 339-345.

55 Ibidem, p. 345, ipsis verbis.

56 Ibidem, p. 346-357. 
Massimi, de acordo com Lelio, havia convertido Covarrubias de réu em amigo, porque não queria problemas com o Conselho Real. Lelio, aborrecido, escreveu duas alegações, sendo que a segunda foi apresentada a Urbano VIII e em cujas palavras finais ele dizia que os ministros reais agiam como se não houvesse Sé Apostólica.

Com efeito, Lelio teve também sérios confrontos com o Conselho das Índias, que também já foram estudados ${ }^{57}$. Lelio sabia que da Igreja das Índias não chegava em Roma nem um único ducado de espólios, enquanto que, de Madri, fluía quase a metade do coletado em toda a Igreja, situação que se prolongaria até 1753. Foi célebre o caso do espólio do bispo Espinosa com que, segundo Leturia, Lelio se deu conta em 1623 do conceito e alcance da teoria do vicariato - ainda que, por se tratar de conseguir o espólio, não acreditasse ser de momento conveniente um ataque frontal àquela, limitando-se a dizer que não deveria estender-se à Espanha, nem mesmo tratando-se de um bispo "indiano" que aqui viesse a morrer.

O fracasso de Lelio foi retumbante nesse assunto, pois, após três meses de gestões, nem sequer pôde inteirar-se sobre quanto ascendia o pecúlio de Espinosa, e o núncio tampouco o deu apoio, preferindo a diplomacia a argumentos jurídicos. Lelio, 18 anos depois, não o esqueceria.

Portanto, nosso coletor saiu de Madri com as piores impressões da política regalista do rei e dos próprios ministros que a executavam. Não deveria nos surpreender, embora não se justifique, que seu parecer contra Solórzano fosse, antes de mais nada, um desquite que encontrava o seu abono - é forçoso dizer - pela italianidade, francofilia e nepotismo que presidiram a política do Urbano $\mathrm{VIII}^{58}$.

3. A obra de Solórzano havia chegado a Roma em 1640, sem que sejam conhecidos os detalhes com exatidão ${ }^{59}$. Provavelmente, o próprio Lelio fez uma censura inicial da mesma, que serviu para que o secretário da Congregação lesse o livro e decidisse que se deveria passar para a censura formal. Lelio ficou encarregado de redigi-la. Em seguida, seria transmitido seu voto impresso a uma reunião de consultores e, posteriormente, com o parecer

57 LETURIA, Pedro de. Antonio Lelio de Fermo y la condenación del 'De Indiarum Iure' de Solórzano Pereira. In: LETURIA, Pedro de. Relaciones entre la Santa Sede e Hispanoamérica: I. Época del Real Patronato, 14931800. Caracas: Sociedad Bolivariana de Venezuela, 1959. p. 358-369.

58 Ibidem, p. 378, ipsis verbis.

59 Sobre o ditame de Lelio, ver: LETURIA, op. cit., p. 386-397; EGAÑA, Antonio de. La teoría del Regio Vicariato español en Indias. Roma: Università Gregoriana, 1958. p. 136-142. 
destes, à reunião plenária de cardeais, cuja sentença o secretário deveria levar ao Papa, para sua decisão final.

Vamos resumir o parecer de Lelio sobre as questões eclesiásticas expostas na obra de Solórzano. Em primeiro lugar, a bula de Alexandre VI concede o domínio das Índias, mas não a jurisdição espiritual: segundo o Concílio de Trento, aos reis se lhes encomenda a defesa dos religiosos, mas não a jurisdição espiritual. Além disso, a bula fala apenas sobre o dízimo. Se a jurisdição tivesse sido concedida, a decisão sobre o dote das igrejas teria sido deixada aos reis, e não aos bispos.

Por outro lado, a Exponi nobis de Gregório XIII concede, a pedido do rei, que se the outorgue poder para aceitar as demandas e apelações de foro eclesiástico; mas o Papa a outorga aos bispos, o que prova, para Lelio, que nem o próprio rei estava ciente de tal jurisdição.

Quanto ao direito inato dos reis, ou regalia, Lelio entende que Solórzano não atua com nitidez, já que defende, por um lado, a autoridade papal, mas, por outro lado, ata as mãos dos juízes eclesiásticos, sem declarar se é por delegação apostólica ou por sua própria potestade política. Para Lelio, Solórzano aceita os dois títulos simultaneamente, quando são contraditórios e não podem coexistir.

Solórzano deduz sua doutrina de dois títulos: da origem divina do poder régio universal - quanto às pessoas e coisas de seu reino - e da potestade econômica que lhe é própria. Mas, sendo o primeiro princípio condenado pelo Concílio de Constança, os eclesiásticos não são súditos do rei, e seus bens gozam de imunidade, o que joga por terra o segundo princípio, um corolário do primeiro ${ }^{60}$.

Quanto ao vicariato régio, Lelio nega que exista, pois nem sequer foi solicitado. Sua opinião sobre os espólios episcopais é opinião própria de cismáticos, porque, embora o costume de longa data seja alegado, foi condenado pela Santa Sé.

Para Lelio, o primeiro tomo do De Indiarum Iure necessita de uma expurgação. O segundo deve ser proibido em sua totalidade, pois atribui ao rei o governo de todas as questões eclesiásticas e de todos os eclesiásticos pela delegação da Sé Apostólica, o que se pretende deduzir das bulas papais sendo, na realidade, uma concessão imaginária.

Com efeito, esta concessão não se baseia no teor expresso do privilégio, mas na interpretação que do mesmo faz a própria vontade do privilegiado ou de seus ministros, como se não fosse necessário o recurso à Sé Apostólica para interpretar o sentido da concessão e 60 EGAÑA, Antonio de. La teoría del Regio Vicariato español en Indias. Roma: Università Gregoriana, 1958. p. 141. 
ignorando que os seculares, por si mesmos, são incapazes de ostentar a jurisdição eclesiástica e espiritual.

Que, pelo uso do tempo ou por permissão usurpada ("usurpata licentia"), é possível adquirir tal jurisdição é digno de condenação, e assim o foi pelos concílios e pelos Papas. Como a obra não tem outro propósito senão atribuir jurisdição espiritual ao rei, a Santa Sé não pode fingir ignorância, nem dissimular tal doutrina ${ }^{61}$.

Esse voto foi submetido à junta de consultores em 1642, que a confirmou substancialmente, mas impondo a restrição de condenar não todo o volume II, como Lelio pretendia, mas seu livro III, De rebus eclesiasticis et de Regio Patronatu, censurando os outros quatro livros deste tomo, bem como o tomo I donec corrigantur, que parece ser usada com os autores católicos dignos de estima.

A condenação é datada de 20 de março de 1642 e é muito semelhante ao estilo do Índice, lacônica e sem explicações ${ }^{62}$.

Mas note-se que, se Lelio foi laminar o livro, Roma - fiel à sua diplomacia - formulou uma condenação mais suave. O que significa mais: não disse uma palavra sobre os motivos da condenação, nem sobre a teoria do régio vicariato. A Congregação do Índice e a de Propaganda Fide a rejeitaram, mas não publicamente; a última o faria em instruções secretas aos núncios, mas não publicamente. A do Índice, por decreto público, mas sem nomear explicitamente a teoria ${ }^{63}$.

É impossível não ver a política na atitude de ambos os dicastérios. O que permitiu seguir defendendo o vicariato "indiano", sob o pretexto de que a condenação não tinha nada a ver com as Índias.

\section{A ATITUDE DA ESPANHA PARA COM ROMA}

Com relação à condenação do De Indiarum Iure, a reação não ocorreu até 1647, quando o fiscal do Conselho das Índias a interpretou como duvidando e se opondo a todos os direitos do rei nas Índias por concessões e bulas apostólicas. No entanto, recorreu-se à via

61 Veja-se o parecer final de Lelio em: EGAÑA, Antonio de. La teoría del Regio Vicariato español en Indias. Roma: Università Gregoriana, 1958. p. 142 et seq.

62 Seu texto: "Librum tertium tomí secundi, omnino et absolute prohiberi; reliquos autem libros, tam primi quam secundi tomi: donec corrigantur". Citado por: EGAÑA, op. cit., p. 146.

63 LETURIA, Pedro de. Antonio Lelio de Fermo y la condenación del 'De Indiarum Iure' de Solórzano Pereira. In: LETURIA, Pedro de. Relaciones entre la Santa Sede e Hispanoamérica: I. Época del Real Patronato, 14931800. Caracas: Sociedad Bolivariana de Venezuela, 1959. p. 396. 
formal de não permitir a sua publicação, entendendo que a Congregação do Índice usurpara as competências da Inquisição espanhola.

Foi feita representação para Roma, mas Filipe IV, em 1647, mandou recolher o decreto com suas cópias, e as remeteu ao Conselho. Censura de censura ${ }^{64}$.

Simplesmente, a Monarquia não queria que Roma se intrometesse nas Índias, porque quebrava sua tradição política de suplantar a autoridade papal, sem excluir que o rei entendesse que estava exercendo seus direitos legítimos e que responderia em consciência a seu abandono. Isso não me parece a razão determinante, mas penso que ninguém queria considerar a licitude ou a antijuridicidade de tal estado de coisas.

A teoria foi aceita e ampliada ${ }^{65}$. A tal ponto que ficou fora de toda discussão, como vale a pena reproduzir a citação do agostiniano Pe. Gaspar de Villaroel - bispo de Santiago do Chile, Arequipa e La Plata - que aceitou sem reservas o vicariato. Ele entendeu que a jurisdição dos reis advinha da delegação papal e, para que se evitassem muitos problemas de consciência - quando, na verdade, não havia nenhum - formulou este princípio apodítico: "Para mim, há duas razões para ter por evidente o privilégio, se bem bastasse o consentimento tácito - despachar cédulas o Conselho e dizê-lo o senhor Solórzano ${ }^{66 "}$.

\section{A QUESTÃO DO PROTESTANTISMO}

As palavras finais do primeiro estudo de Leturia ${ }^{67}$ convidam a uma séria reflexão sobre essa questão que, exceto ele mesmo e De la Hera, e de forma muito breve, ninguém havia formulado com profundidade. O próprio Leturia quer deixar a salvo a consciência e a altura dos ideais da Coroa, mas creio que pode afundar-se mais em tão complicada questão, sempre e quando fique assentada a evidência de que os reis da Espanha não aderiram à doutrina de Lutero.

64 LETURIA, Pedro de. Antonio Lelio de Fermo y la condenación del 'De Indiarum Iure' de Solórzano Pereira. In: LETURIA, Pedro de. Relaciones entre la Santa Sede e Hispanoamérica: I. Época del Real Patronato, 14931800. Caracas: Sociedad Bolivariana de Venezuela, 1959. p. 397-408; EGAÑA, Antonio de. La teoría del Regio Vicariato español en Indias. Roma: Università Gregoriana, 1958. p. 147-150.

65 Ver o desenvolvimento em: EGAÑA, op. cit., p. 151-172.

66 Citado por: EGAÑA, op. cit., p. 159.

67 "Con sus defectos y todo, el Vicariato regio de Indias fue Vicariato, no supremacía anglicana; y aún como Vicariato sin la vocación misionera de la Corona y nación españolas y sin la seriedad con que el rey y sus súbditos se afanaron 'por el descargo de la real conciencia'”. LETURIA, Pedro de. El regio vicariato de Indias y los comienzos de la Congregación de Propaganda. In: LETURIA, Pedro de. Relaciones entre la Santa Sede e Hispanoamérica: I. Época del Real Patronato, 1493-1800. Caracas: Sociedad Bolivariana de Venezuela, 1959. p. 152. 
Mas, se descartamos esse protestantismo teórico e olhamos desapaixonadamente a realidade do vicariato "indiano", em sua concepção teórica e em sua aplicação prática, podemos assinalar interessantes pontos de contato. Vê-se claramente que os vicarialistas dos primeiros cem anos da teoria sempre a fundaram na suposta concessão papal. Mas, não caberia admitir uma semelhança entre o exercício da jurisdição em assuntos eclesiásticos pelo rei e seus ministros, com a que exercem outros príncipes protestantes como chefes de suas igrejas nacionais?

Porque as alusões ao luteranismo foram dadas, e muito cedo, pelos protagonistas da história. Já foi mencionado que em 1591, o Concílio de Lima comunicou aos superiores das Ordens a resposta de Roma às dúvidas propostas por São Toribio de Mogrovejo, concretamente a 23, no sentido de que o breve de Pio V estivesse revogado, e os regulares devessem ser examinados segundo o Concílio de Trento. O provincial dos mercedários respondeu que o referido breve havia sido concedido ao rei como patrono das Índias e não poderia ser revogado sem ser ouvido, e que ditas declarações não foram endossadas pelo Conselho das Índias.

O bispo de Cuzco, o dominicano Gregorio Montalvo de Coca, replicou que o rei não é intérprete do Concílio nem de bulas papais, para acrescentar, ato contínuo, várias atuações em que, em seu entender, eram luteranismo: defender o passe régio e reter as bulas. Resolveu a gosto o bispo, terminando com que os Conselhos de Castela e Índias não tinham título nenhum para isso, e que, para não escandalizar o mundo, não os declarasse o Papa excomungados ${ }^{68}$.

O Pe. Luis de Miranda, um dos religiosos vicarialistas, assinala um conceito mais avançado da teoria, dizendo que são os reis que dão as licenças ministeriais, na qualidade de vigários e delegados da Sé Apostólica. E os facultados diretamente pelo rei não incorrem em excomunhão, pois atuam em comunhão com o legado do Papa ${ }^{69}$.

Como ocorreu logo com a condenação de Solórzano, quando foram condenados os livros de Ceballos e Salgado de Somoza, Felipe IV escreveu ao cardeal Borja anunciando que, se em Roma fossem proibidas as obras que defendiam os direitos régios, ele se encarregaria de proibir as que viessem a propugnar os direitos papais; e encomendava ao cardeal que

68 LETURIA, Pedro de. El regio vicariato de Indias y los comienzos de la Congregación de Propaganda. In: LETURIA, Pedro de. Relaciones entre la Santa Sede e Hispanoamérica: I. Época del Real Patronato, 1493-1800. Caracas: Sociedad Bolivariana de Venezuela, 1959. p. 129 et seq.; EGAÑA, Antonio de. La teoría del Regio Vicariato español en Indias. Roma: Università Gregoriana, 1958. p. 91.

69 Ibidem, p. 96 et seq. 
suplicasse ao Papa que, em questões que não fossem de fé, mas de jurisdição, deixasse atuar cada um, para dizer o que julgava mais certo ${ }^{70}$.

Mesmo quando Felipe IV ordenou a retirada do decreto que condenava a obra de Solórzano, suplicou a Roma que o Papa, mais bem informado dos direitos que pertenciam ao rei nas Índias, se servisse de reformar o decreto referido ${ }^{71}$.

Estes são alguns exemplos do que, com as reservas necessárias, poderia ser chamado de protestantismo prático. O professor De la Hera se deteve a meditar sobre a influência que a reforma luterana teve sobre o regalismo. Mas antes de aduzir a seu pensamento, será bom expor o que se pode chamar de teologia do absolutismo de Martinho Lutero ${ }^{72}$.

Sabe-se que o luteranismo resolveu a famosa controvérsia entre o poder pontifício absoluto e a preeminência do concílio sobre o papa de maneira radical: mediante a supressão da ordem eclesiástica em geral e a secularização de todo poder que afetasse o mundo terrenal. $\mathrm{Na}$ ordem temporal, o estado eclesiástico é descrito por Lutero como um pseudo-Estado e uma Igreja depravada, de onde, portanto, deve ser abolido.

Em seu trabalho sobre autoridade temporal, Lutero entende que o governo temporal e o governo espiritual são exercidos em paralelo, em dois planos completamente diferentes: um exterior, simbolizado pela espada, e outro interior, que não pode estar sujeito a restrições, porque é inteiramente livre. Essa dualidade implica que toda autoridade temporal conflua nos poderes seculares estabelecidos, que são os únicos que podem modificar as leis.

O que conduz, pura e simplesmente, ao absolutismo do poder temporal, é mais: a obediência ao poder estabelecido, independentemente de sua confissão religiosa, convertendose em regra absoluta, de tal maneira que inclusive se exclui qualquer direito dos súditos a reunir-se para qualquer deliberação.

Ao mesmo tempo, Lutero sataniza o "papismo", enquanto pretende que ao Papa lhe assistem todos os direitos, e que tudo o que ele ordena e decide com sua Igreja deva ser

70 EGAÑA, Antonio de. La teoría del Regio Vicariato español en Indias. Roma: Università Gregoriana, 1958. p. 131 et seq.

71 LETURIA, Pedro de. El regio vicariato de Indias y los comienzos de la Congregación de Propaganda. In: LETURIA, Pedro de. Relaciones entre la Santa Sede e Hispanoamérica: I. Época del Real Patronato, 1493-1800. Caracas: Sociedad Bolivariana de Venezuela, 1959. p. 150. Lembro que, quando no IX Congresso do Instituto Internacional de História do Direito Indiano, realizado em Madri em 1990, na exposição das teorias do Pe. Avendaño, aludi ao fato de que os regalistas sempre invocavam a doutrina da deficiente informação papal: se o Papa estivesse melhor informado dos direitos do rei, não teria disposto o que dispôs; que serviu para reter as bulas que atentavam contra os direitos do rei, fossem reais ou supostos. O professor A. de la Hera, em colóquio, disse que essa era exatamente a argumentação de Lutero, quando publicou suas famosas proposições contra a bula papal na igreja-castelo de Wittenberg. Foi essa afirmação com a qual me confrontei, desde uma nova perspectiva, com o vicariato indiano.

72 Sigo aqui o trabalho citado na nota 10 . 
considerado como justo, inclusive quando extrapola as Escrituras. Dada essa perversidade, o poder papal deve desaparecer, para que o temporal fique livre das aspirações de realizar neste mundo os ideais cristãos do Direito divino. O reinado de um príncipe não se sujeita mais que ao Juízo Final, como a atuação de qualquer outro, mas, enquanto isso, o dever de obediência ao príncipe é universal, porque expressa a essência de todo Direito divino: o princípio da submissão do inferior ao superior.

Este não é o lugar para fazer uma crítica teológica do pensamento luterano, todo ele motivado e misturado com componentes políticos. Mas sim, cabe assinalar simplesmente que há uma deslegitimização do poder pontifício e uma sacralização do poder temporal dos príncipes.

Por isso, como diz De la Hera ${ }^{73}$, não é de se surpreender que Lutero tivesse confiado o supremo poder das igrejas reformadas ao poder civil, de modo que os príncipes protestantes se convertessem em chefes de suas respectivas igrejas. Claro está que as monarquias católicas se mantinham fiéis ao Papado, mas, ao mesmo tempo, ansiavam pelas faculdades do governo espiritual que em tão ampla margem tinham as monarquias protestantes.

E, portanto, quiçá inconscientemente, produziu-se uma aproximação das monarquias católicas às teses regalistas. O regalismo aparece como uma heresia administrativa, porque não afeta o dogma, mas praticamente permite discutir e até ignorar os direitos legítimos do Papa no governo espiritual da Igreja $^{74}$. E no século XVIII, o regalismo se estenderia uniformemente por toda a Europa católica.

Não nos toca examinar esse período, mas sim dizer, a título de recapitulação deste último apartado, que não é estranho que alguns eclesiásticos, alarmados, apodem certas atitudes regalistas do luteranismo, sem, no entanto, chamar os reis e seus ministros de protestantes. Mas, se estes tivessem colocado em questão aspectos dogmáticos, especialmente a condição do Papa como Vigário de Cristo e cabeça da Igreja, teriam caído diretamente no protestantismo. Por essa razão, o vicariato parece tão heterodoxo, se for julgado desde uma perspectiva religioso-doutrinal, ainda que o seja muito menos se for simplesmente observado nele o culminar, a favor do rei, de um conflito de jurisdições.

73 HERA, Alberto de la. Iglesia y Corona en la América española. Madri: Mapfre, 1992. p. 398 et seq.

74 Ver a interessante concomitância entre a doutrina luterana anteriormente exposta e as conclusões galicanas da Assembleia do Clero francês, celebrada em 1682 sob o reinado de Luís XIV (HERA, Alberto de la. Iglesia y Corona en la América española. Madri: Mapfre, 1992. p. 398). 


\section{CONCLUSÕES}

De tudo o que foi dito, pode-se formular o seguinte:

1. Os estudos sobre o régio vicariato das Índias não incidiram suficientemente, salvo exceções, na natureza e finalidade política da teoria, e, portanto, ficam incompletos ao estudálo simplesmente de uma perspectiva jurídica.

2. A teoria vicarial é, em si mesma, política. Não trata de atentar contra o dogma, mas privar o Papa de todo poder jurisdicional nas Índias. Em outras palavras, prescinde, de fato, de qualquer aspecto pastoral, mesmo que, por puro oportunismo, se diga às vezes o contrário.

3. No seu nascimento, o vicariato se deve ao aporte dos religiosos, que buscam afastarse do poder dos bispos, com o débil fundamento do destinare debeatis da concessão alexandrina. Os religiosos atuam com parcialidade manifesta, aceitando a teoria no que os beneficia e se apartando dela no que os prejudica.

4. A Monarquia aceita plenamente essa teoria, porque politicamente é conveniente aos seus interesses, evitando qualquer dúvida sobre sua licitude e até mesmo sua veracidade, mesmo antes do século XVIII. Assim, ampara-se de um instrumento formidável, que lhe permite atuar contra Roma, favorecer os religiosos quando lhe convém, e fazer o mesmo com os bispos - contra estes quando os primeiros querem conservar um protagonismo excessivo.

5. A sacralização civil, produzida pela obra de Solórzano, é contestada pela amarga condenação de Antonio Lelio de Fermo, em que não cabe ignorar a sua disposição anímica, propensa à vingança, pelos desrespeitos recebidos durante sua estadia em Madri.

6. A Santa Sé atua, em relação ao vicariato, de maneira diplomática, condenando a teoria de modo secreto, ou ao menos não publicamente, a fim de não provocar uma situação de ruptura com a monarquia católica, que ademais assegura às suas custas a evangelização das Índias.

7. Esta, a última razão para as atuações de Roma e Madri, parece muito desalinhada na formulação e aplicação prática da teoria vicarial. Os religiosos não hesitam em defendê-la, mesmo quando sabem que muitos com a cura de almas são ministros indignos. $\mathrm{O}$ rei, o mesmo, sem que disso possa pretextar ignorância, mas lhe importa, acima de tudo, a defesa de seus direitos. E Roma, como sempre, trata de coonestar a sua missão apostólica com sua escassez de meios e com as próprias políticas que os Papas empreendem enquanto soberanos temporais. 


\section{REFERÊNCIAS}

ALONSO, Santiago. El pensamiento regalista de Francisco Salgado de Somoza (1595-1665): Contribución a la historia del Regalismo español. Salamanca: Instituto San Raimundo de Peñafort C.S.I.C, 1973.

ARRIETA ALBERDI, Jon. El Consejo Supremo de la Corona de Aragón (1494-1707). Zaragoza: Instituto Fernando el Católico, 1994.

ARVIZU, F. Don Pedro Frasso y la inmunidad eclesiástica. Anuario de Historia del Derecho Español. Madri, n. 56, 1986.

ARVIZU, F. El pensamiento jurídico del P. Diego de Avendaño. S.I. Notas de interés para el Derecho Indiano. In: Actas del IX Congreso del Instituto Internacional de Historia del Derecho Indiano. v. I. Madri: Universidad Complutense, 1991.

ARVIZU, F. El pensamiento regalista de Don Pedro Frasso en su obra 'De Regio Patronatu Indiarum'. Revista Chilena de Historia del Derecho, Santiago de Chile, n. 12, 1986.

CANTELAR RODRÍGUEZ, Francisco. El Patronato regio de Indias en Solórzano Pereira. In: SOLÓRZANO PEREIRA, Juan de. De Indiarum Iure. Lib. III: De retentione Indiarum. Madri: CSIC, 1994.

CANTELAR RODRÍGUEZ, Francisco. Patronato y vicariato regio español en Indias. In: AA.VV. Derecho canónico y pastoral en los descubrimientos luso-españoles y perspectivas actuales: XX Semana Luso-Española de Derecho Canónico. Bibliotheca Salmanticensis. Estudios, n. 112. Salamanca: Universidad Pontificia de Salamanca, 1989.

EGAÑA, Antonio de. La teoría del Regio Vicariato español en Indias. Roma: Università Gregoriana, 1958. (Analecta Gregoriana: Series Facultatis Historiae Ecclesiasticae, v. 95).

HERA, Alberto de la. El Patronato y el Vicariato Regio en Indias. In: BORGES, Pedro (dir.). Historia de la Iglesia en Hispanoamérica y Filipinas. v. 1. Madri: BAC, 1992.

HERA, Alberto de la. El regalismo indiano. In: BORGES, Pedro (dir.). Historia de la Iglesia en Hispanoamérica y Filipinas. v. 1. Madri: BAC, 1992.

HERA, Alberto de la. El regalismo borbónico en su proyección indiana. Madri: Rialp, 1963.

HERA, Alberto de la, Alberto. Iglesia y Corona en la América española. Madri: Mapfre, 1992. 
LETURIA, Pedro de. Antonio Lelio de Fermo y la condenación del 'De Indiarum Iure' de Solórzano Pereira. In: LETURIA, P. Relaciones entre la Santa Sede e Hispanoamérica: I. Época del Real Patronato, 1493-1800. Caracas: Sociedad Bolivariana de Venezuela, 1959.

LETURIA, Pedro de. El regio vicariato de Indias y los comienzos de la Congregación de Propaganda. In: LETURIA, Pedro de. Relaciones entre la Santa Sede e Hispanoamérica: I. Época del Real Patronato, 1493-1800. Caracas: Sociedad Bolivariana de Venezuela, 1959.

LOPETEGUI, León; ZUBILLAGA, Félix. Historia de la Iglesia en la América española. v. I. Madri: BAC, 1965.

SÁNCHEZ BELLA, Ismael, Historiografía de las instituciones jurídicas indianas (19451987). In: VÁZQUEZ DE PRADA VALLEJO, Valentín; OLÁBARRI GORTÁZAR, Ignacio (coord.). Balance de la Historiografía sobre Iberoamérica (1945-1988): Actas de las IV Conversaciones Internacionales sobre Historia (Pamplona - 10-12 marzo 1988). Pamplona: EUNSA, 1989.

SÁNCHEZ BELLA, Ismael. Iglesia y Estado en la América española. 2. ed. Pamplona: EUNSA, 1991.

SCHAUB, Marianne. La réforme luthérienne: une théologie de l'absolutisme. In: GENET, Jean-Philippe; VINCENT, Bernard (coord.). État et Église dans la genèse de l'État Moderne. Bibliothèque de la Casa de Velázquez. n. 1. Madri: Casa de Velázquez, 1986.

\section{DADOS DA PUBLICAÇÃO}

Categoria: artigo de autor convidado.

Recebido em: 01/03/2020.

Aceito em: 10/03/2020. 